\title{
多発胁骨骨折を伴う鈍的胸部外鹪により 遲発性心破裂を来した1例
}

冨岡百合子 ${ }^{1}$ 吉 ${\text { 村 }{ }^{2} \text { 福岡 } \text { 正人 }^{3} \text { 辰巳 嘉章 }}^{3}$

\begin{abstract}
要旨 61 歳の男性。高さ $1.5 \mathrm{~m}$ の塀から転落して左側胸部を打撲し, 当院に入院した。来院時, 意識清明でvital signs も安定していた。胸部CTで左多発肋骨骨折と血気胸を認め, 胸腔ドレナー ジを行った。受傷より 56 時間後, 突然の意識消失を来し，橈骨動脈を触知できなかったため胸骨 圧迫を行ったところ，直後に意識は改善した。その短時間で胸腔ドレーンょり血性排液 $140 \mathrm{~mL}$ の増加がみられ，胸部造影 CTでは心臓周囲に血管外漏出を認めた。左第 5 肋間より側方開胸し たところ，第 5 肋骨骨折端が鋭利に突出して心囊に接しており，その直下より出血を認めた。心 膜を切開すると血液が噴出し，心尖部近くの左心室に $10 \mathrm{~mm} の 心$ 筋破裂がみられた。フェルト短 冊を扔いてポリプロピレン糸で水平マットレス縫合を行い，止血を得た。本例では，来院時に心 囊液貯留を認めなかったことから, 肋骨骨折端が心筋を貫いたのではなく, 心筋に長時間接して いたことで遅発性心破裂に至ったものと考えられた。多発胁骨骨折を伴う鈍的胸部外傷では，受 傷後の遅発性心破裂を念頭におくべきである。
\end{abstract}

（日救急医会誌. 2014; 25: 827-32）

キーワード：心タンポナーデ, 左室破裂, 血気胸, 非貫通性

\section{はじめに}

鈍的胸部外傷では, 肺損傷, 胁骨損傷, 大血管損 傷のみならず，比較的稀ではあるが心損傷も合併す る。心損傷は致死的であり, 病院に搬送されるまで の死亡率は非常に高く ${ }^{1)}$, 的確な診断と迅速な対応 が求められる。我々は, 鈍的胸部外傷による多発肋 骨骨折, 血気胸に対して保存的加療中に遅発性心破 裂を来し，緊急手術により救命し得た症例を経験し たので報告する。

Delayed cardiac rupture after blunt chest trauma associated with multiple rib fractures

${ }^{1}$ 耳原総合病院外科

2 星優クリニック

3 製鉄記念広畑病院外科

著者連絡先：=590-8505 大阪府堺市堺区協和町 4丁 465

原稿受理日：2014年 8 月 20 日（14-059）
症例

患 者：61歳の男性

主 訴: 左側胸部打撲

既往歴：特記すべきことなし

現病歴：高さ $1.5 \mathrm{~m}$ の塀から転落し左側胸部を打 撲して受傷した。近医で左胁骨骨折と軽度の血胸と 診断されて帰宅し，翌日のレントゲンで血胸の増悪 を認めたため紹介受診した。

入院時現症（受傷より 24 時間後）:独歩にて来院。 意識レベル Glasgow coma scale 15（E4V5M6），心拍 数 75 /分, 収縮期血圧 $125 \mathrm{mmHg}$, 呼吸数 10 / 分であっ た。左胸壁 flailing や肋骨軋䡕音はなく, 軽度の皮 下気腫を認めた。

来院時検査所見：胸部レントゲンでは左多発胁骨 骨折と血気胸を認めた。血液学検査では軽度の炎症 所見と CK $379 \mathrm{IU} / \mathrm{L}$ と軽度上昇を認めた。貧血は認 

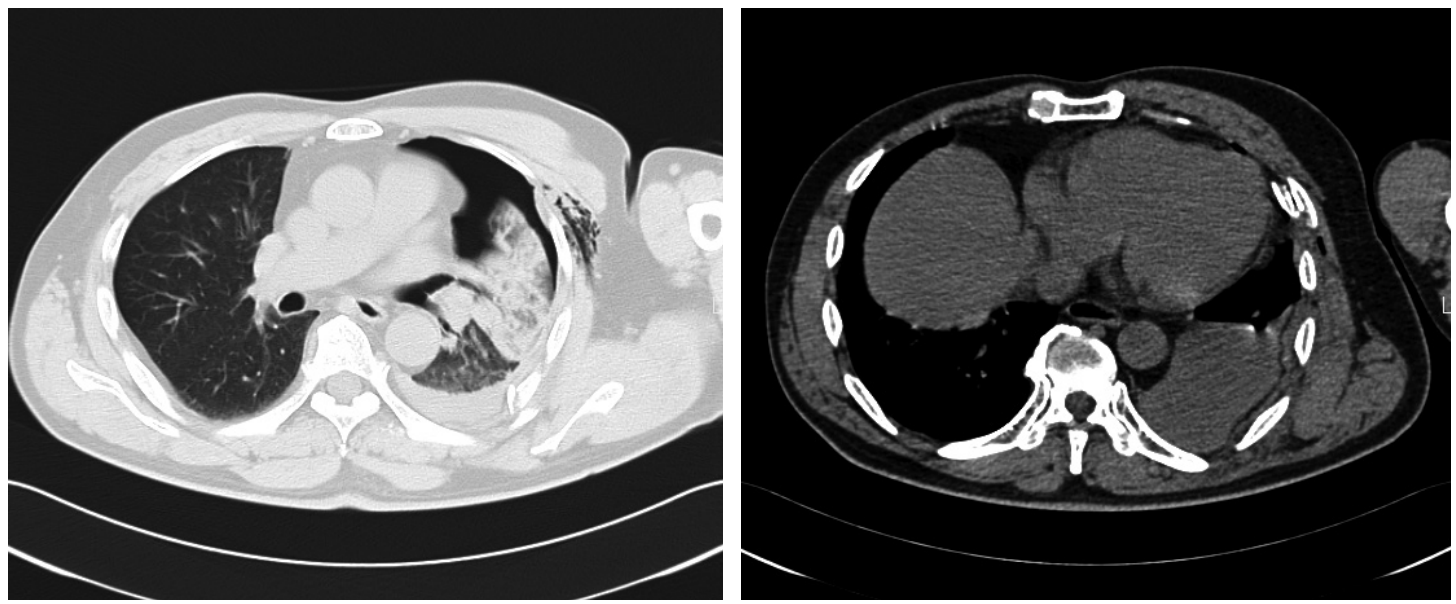

Fig. 1. Computed tomography scan on admission, showing a portion of the fractured left fifth rib close to the left ventricle and hemopneumothorax, but no pericardial effusion.

めなかった。胸部単純 CT 検査では, 左血気胸と左 第3-9胁骨骨折を認め, そのうち第4-6肋骨は2箇所 の骨折を認めた (Fig. 1)。心囊液貯留は認めなかっ た。左第4肋間前腋窩線より20Frの胸腔ドレーンを 挿入したところ air leakage と少量の血性胸水を認め, $-10 \mathrm{cmH}_{2} \mathrm{O}$ 持続吸引で入院加療とした。

入院後経過：受傷から 48 時間後にあたる入院 2 日 目には胸腔ドレーンからの air leakage は消失し, 血 性排液は 240mL/24hrで vital signs も安定していた。 受傷から 56 時間後，気分不良の訴えがあり突然の 意識消失を認めた。橈骨動脈を触知しなかったため 心肺停止と判断して蘇生処置を開始したところ, 胸 骨圧迫 2 回で意識は改善した。その短時間で胸腔ド レーンより血性排液 $140 \mathrm{~mL}$ の増加がみられ，その 後も血性排液の持続を認めた。胸部造影 CTでは左 胸腔内に大量の血腫がみられ, 心尖部付近に造影剤 の血管外漏出を認めた (Fig. 2)。心囊液貯留は認め なかった。細胞外液の急速補液と輸血を行ったが血 圧は低下し, 再度心肺停止となったため心肺蘇生を 行い，緊急手術を施行した。その間も胸腔ドレーン の血性排液は持続し， $1,800 \mathrm{~mL}$ の貯留がみられた。

手術所見：全身麻酔, 右片肺換気下に左側臥位に て左第 5 肋間側方開胸を実施したところ，第 5 肋骨 骨折端が胸腔内に鋭利に突出しており（Fig. 3a），直 下の心囊損傷部位より出血を認めた。損傷した心外
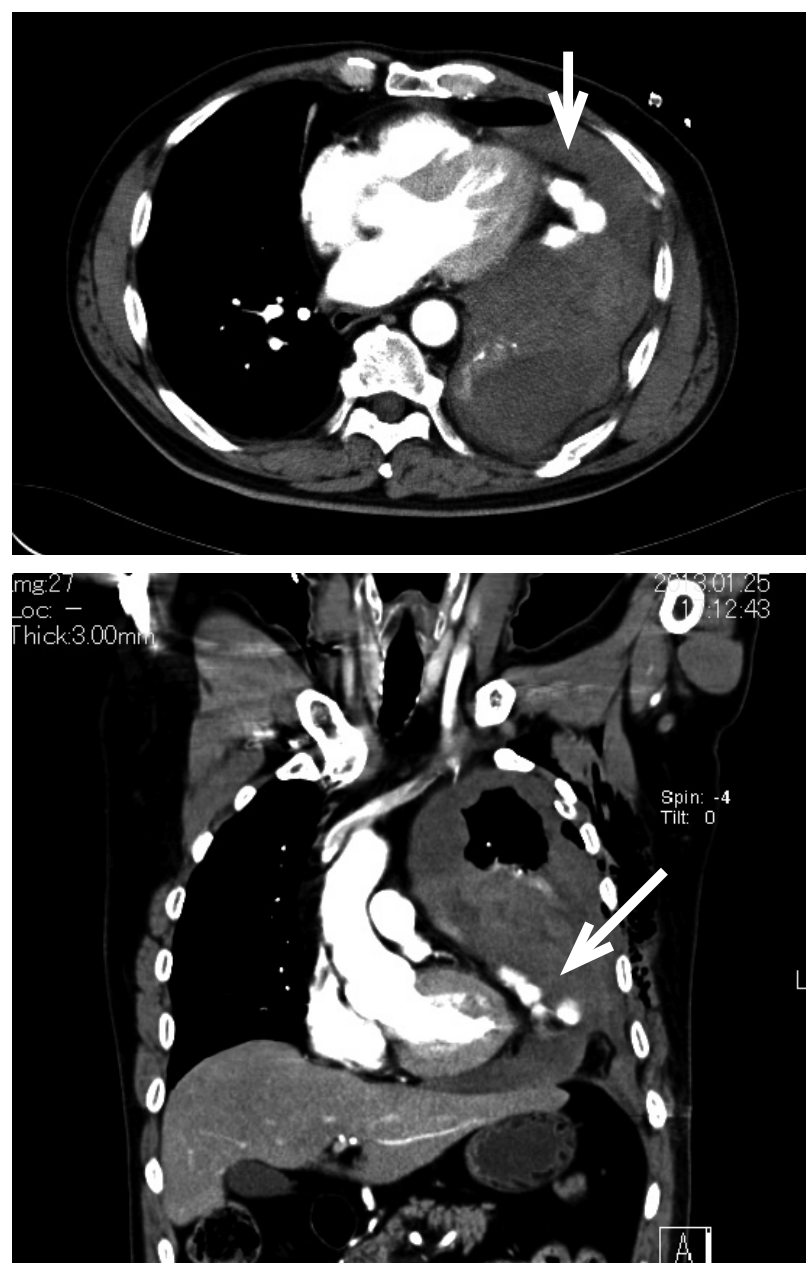

a Fig. 2. Computed tomography scan at 56h after injury

b shows a large thoracic cavity hematoma and extravasation around the heart apex (arrow). 

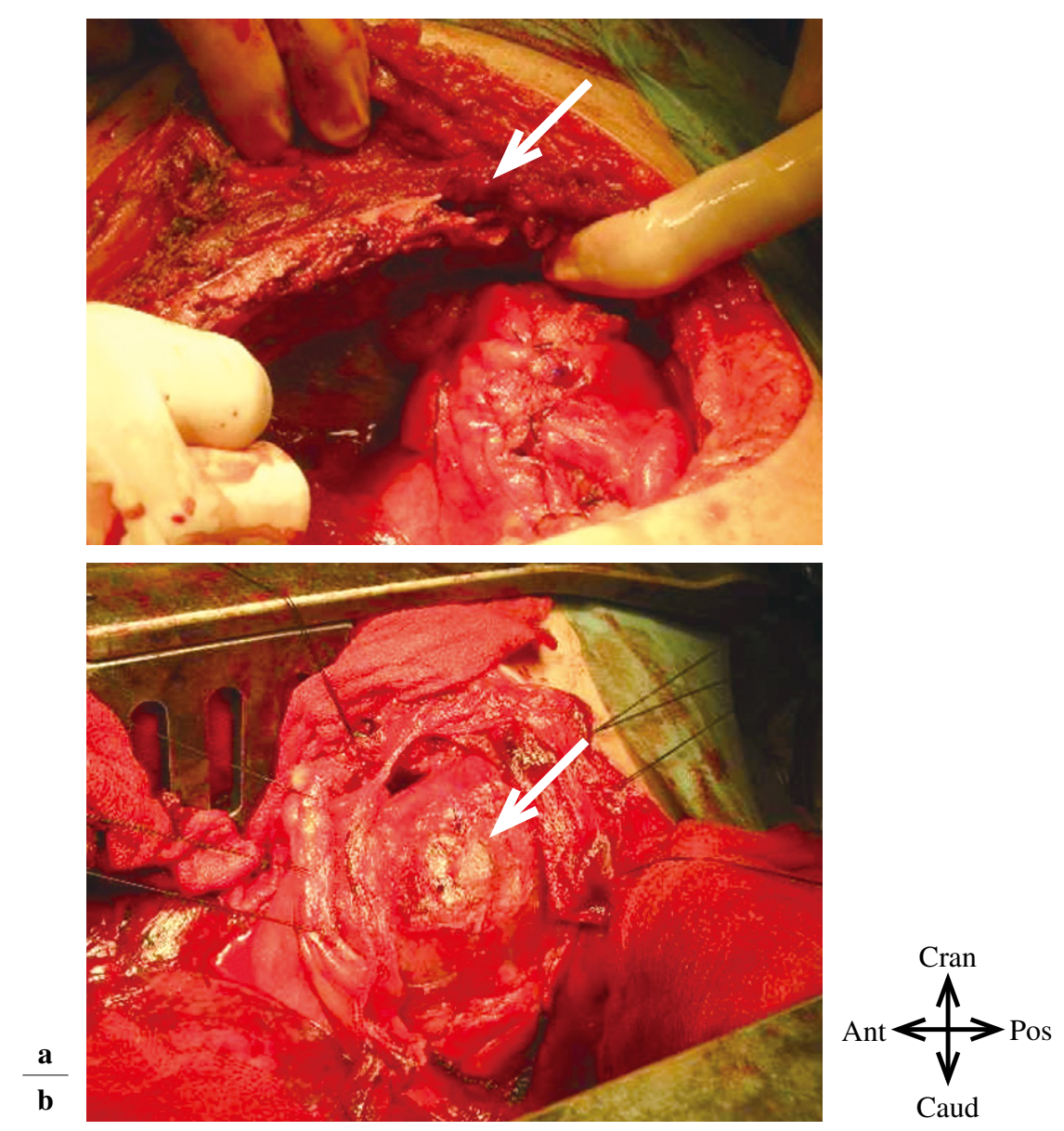

Fig. 3. Surgical view.

a: the fifth rib fracture (arrow).

b: the 10-mm rupture to the left ventricle close to the apex (arrow).

膜を切開すると血液が噴出し, シート状生物学的組 織接着剤と用手圧迫で出血をコントロールして視野 を確保したところ，心尖部付近の左心室に $10 \mathrm{~mm} の$ 心筋破裂を認め，心尖部心損傷（IIIa型 $\mathrm{Tp}$ ） と診断 した (Fig. 3b)。スタビライザーを用いて, 損傷部位 に $10 \mathrm{~cm} \times 1 \mathrm{~cm}$ のフルト短冊を2枚置き, プレジェッ 卜付 3-0 ポリプロピレン糸で水平マットレス縫合を 行い止血を得た。左第5-6肋骨骨折断端を胁骨剪刃 でそれぞれ約 $5 \mathrm{~cm}$ 離断してヤスリをかけ骨蝋を塗布 した。観血的固定術は行わなかった。左前腋窩線第 7 肋間より横隔膜に沿い背側へ向かって $20 \mathrm{Fr}$ の胸腔 ドレーンを留置して閉胸し, 手術を終了した。総輸 血量は濃厚赤血球製剤が 18 単位, 新鮮凍結血漿製剤 が12単位であった。
術後経過：止血処置と術中輸液・輸血にて血圧は 改善し, 術後カテコラミンサポートは行わず循環動 態は安定した。周術期に不整脈や心不全等の心機能 障害はなく, 第6病日に抜管, 第11病日に胸腔ドレー ンを抜去し，第20病日に独歩退院した。

\section{考察}

鈍的胸部外傷による心損傷例は非常に少ないが致 死的な病態であり, 病院に搬送されるまでの生存率 はその $20 \%$ 以下である1)。心損傷には心挫傷, 心破 裂, 心室中隔破裂, 三尖弁破裂, 冠動脈静脈瘦, 僧 房弁乳頭筋断裂などがある。なかでも心破裂は全外 傷のうち $0.041 \%$ と稀で, その死亡率は $80 \%$ 以上と 非常に高い ${ }^{2,3}$ 。損傷部位は, 右心室が $46 \%$ と最も多 
Table1. Reportedcases of cardiac injury following a fractured rib due to blunt chest trauma.

\begin{tabular}{|c|c|c|c|c|c|c|c|c|}
\hline Year & Author & $\begin{array}{l}\text { Age } \\
\mathrm{M} / \mathrm{F}\end{array}$ & Onset & $\begin{array}{l}\text { Rib } \\
\text { fracture }\end{array}$ & Period of onset & $\begin{array}{l}\text { Cardiac } \\
\text { injury }\end{array}$ & $\begin{array}{l}\text { Size of } \\
\text { injury }\end{array}$ & Outcome \\
\hline 1996 & Bourguignon $\mathrm{N}^{4)}$ & $60 \mathrm{M}$ & $\begin{array}{l}\text { motor vehicle } \\
\text { accident }\end{array}$ & 4- 9 th & $\begin{array}{l}\text { a few hours } \\
\text { later }\end{array}$ & $\mathrm{RV}$ & unknown & unknown \\
\hline 1993 & Galvin $\mathrm{IF}^{5)}$ & $41 \mathrm{~F}$ & $\begin{array}{l}\text { motor vehicle } \\
\text { accident }\end{array}$ & 5-7th & $\begin{array}{l}\text { a few days } \\
\text { later }\end{array}$ & LV & unknown & alive \\
\hline 2006 & Pankai $\mathrm{K}^{6)}$ & $55 \mathrm{M}$ & fall & 5th 6th & on admission & LV & $15 \mathrm{~mm}$ & alive \\
\hline 1989 & Glock $Y^{7)}$ & 25 & $\begin{array}{l}\text { motor vehicle } \\
\text { accident }\end{array}$ & unknown & on admission & LV & $50 \mathrm{~mm}$ & death \\
\hline 1989 & Glock $Y^{7)}$ & $30 \mathrm{~F}$ & $\begin{array}{l}\text { motor vehicle } \\
\text { accident }\end{array}$ & 5 th & 15 days later & LV & $20 \mathrm{~mm}$ & alive \\
\hline 2002 & Roth $\mathrm{T}^{8)}$ & $33 \mathrm{M}$ & $\begin{array}{l}\text { motor vehicle } \\
\text { accident }\end{array}$ & unknown & 6 hours later & LV & $15 \mathrm{~mm}$ & alive \\
\hline 2010 & Nakamura $\mathrm{K}^{9)}$ & $27 \mathrm{~F}$ & $\begin{array}{l}\text { motor vehicle } \\
\text { accident }\end{array}$ & 8th 9th & 10 hours later & LV & $12 \mathrm{~mm}$ & alive \\
\hline 2013 & Tomioka Y & $61 \mathrm{M}$ & fall & 5- 9 th & 56 hours later & LV & $10 \mathrm{~mm}$ & alive \\
\hline
\end{tabular}

いとされており, 左心室, 右心房と続くが, 心挫傷 による二次性心破裂では, 右心房が $41 \%$ と最も多く, 右心室 $31 \%$, 左心房 $25 \%$, 左心室 $9 \%$ とされる ${ }^{2)}$

鈍的胸部外傷の胁骨骨折による心損傷は極めて稀 であり，いくつかの報告が散見される（Table 1）。 原因は交通外傷，転落などで，多発肋骨骨折を伴う ものが多く，左第 5 肋骨骨折端による左心室損傷が 多くみられた 4-7)。穿通性心損傷だけでなく, 胁骨骨 折端の転位による心挫傷が，受傷から数時間または 数日経過後に遅発性心破裂を来した症例も報告され ている ${ }^{7-9)}$ 。術前に肋骨外固定術を施行された症例は なく，術式はいずれも心破裂部位のモノフィラメン 卜糸による縫合術と心破裂の原因となった胁骨切断 除去術，肺損傷合併例では肺葉部分切除術であっ た。本症例では入院時にフレイルチェストや呼吸不 全等の所見を認めなかったため胁骨外固定術の適応 外と判断したが，胸腔内に転位した第 5 肋骨断端が 心尖部直上にあったことから, 遅発性心破裂を回避 すべく，予防的胁骨外固定術も考慮すべきであった かもしれない。遅発性心破裂の症例報告自体が少な く，その予防については未だ議論の余地がある。

鈍的胸部外傷による心破裂の発生機序は, (1)胸骨 と脊柱の間の圧迫による心破裂，(2)直接または間接 的な胸腔内圧の上昇, (3)心挫傷に続いて生じる心筋
の壊死や軟化により受傷後数時間から数か月でおこ

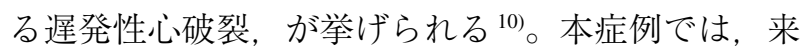
院時に心囊液貯留を認めなかったことから, 肋骨骨 折端が心筋を貫いたのではなく，心筋に長時間接し ていたことで遅発性心破裂に至ったものと考えられ た。Uedaらは，受傷から 2 か月後に遅発性心破裂を 生じた症例で, 病理検查所見で心筋層がフィブリン 沈着に置換されていたことから，心筋断裂後に間質 性出血と限局性の壊死を来した可能性があると報告 している ${ }^{11)}$ 。これは2か月間胁骨骨折断端が心筋に 接していたことにより時間依存性に心筋の変性が生 じたものと思われる ${ }^{12)}$

また胸骨圧迫直前の心囊液貯留の確認はできてい ないが，心肺停止直前までvital signsが安定してい たことや胸腔ドレーン排液の増加を認めなかったこ となどから，胸骨圧迫による肋骨骨折端の貫通性心 損傷は否定的である。技そらく，遅発性心破裂によ る心タンポナーデが原因で突然の心肺停止を来した が，心囊腔内の圧が高まるとともに心外膜の損傷部 位より血液が排出されたことで心タンポナーデが解 除され，胸腔ドレーンからの血性排液が増加したと 考えられた。この心外膜の損傷は, 肋骨骨折端によ り受傷時に損傷した可能性と, 胸骨圧迫により損傷 した可能性がある。鈍的心損傷による心タンポナー 
デの場合，心囊にも損傷が存在すると心囊腔と胸腔 内に交通ができ，血液がある程度流出して一時的な 心タンポナーデの解除を得られるとされている9

本症例では, 心夕ンポナーデ解除後も大量出血が 続いたため再度の心停止が生じたものと考えられ た。多発胁骨骨折を伴う鈍的胸部外傷では, 受傷後 の遅発性心破裂を念頭におき, 閉塞性ショック, 出 血性ショックのいずれも考慮する必要がある。

\section{まとめ}

鈍的胸部外傷による多発胁骨骨折，血気胸に対し て保存的加療中に遅発性心破裂を来し手術により救 命し得た 1 例を経験した。多発肋骨骨折を伴う鈍的 胸部外傷では，受傷後の遅発性心破裂も念頭におく ベきである。

本論文における利益相反はない。

\section{文献}

1) Calhoon JH, Grover FL, Trinkle JK: Chest trauma. Approach and management. Clin Chest Med. 1992; 13: 55-67.

2) Brathwaite CE, Rodriguez A, Turney SZ, et al: Blunt traumatic cardiac rupture. A 5-year experience. Ann Surg. 1990; 212: 701-4.

3) Teixeira PG, Inaba K, Oncel D, et al: Blunt cardiac rupture: a 5-year NTDB analysis. J Trauma. 2009; 67: 788-91.

4) Bourguignon N, Godier S, Genevois A, et al: Heart injury following closed thoracic injury. Ann Fr Anesth Reanim. 1996; 15: 1088-9.

5) Galvin IF, Costa R, Murton M: Fractured rib with penetrating cardiopulmonary injury. Ann Thorac Surg. 1993; 56: 558-9.

6) Kaul P, Somsekhar G, Macauley G: Secondary left ventricular injury with haemopericardium caused by a rib fracture after blunt chest trauma. J Cardiothorac Surg. 2006; 1: 8.

7) Glock Y, Massabuau P, Puel P: Cardiac damage in nonpenetrating chest injuries. Report of 5 cases. J Cardiovasc Surg. 1989; 30: 27-33.

8) Roth T, Kipfer B, Takala J, et al: Delayed heart perforation after blunt trauma. Eur J Cardiothorac Surg. 2002; 21: 121-3.

9) 中村健, 外山秀司, 中嶋和恵, 他: 左肋骨骨折による外傷 性左室損傷. 胸部外科. 2010; 63: 194-7.

10) Pevec WC, Udekwu AO, Peitzman AB: Blunt rupture of the myocardium. Ann Thorac Surg. 1989; 48: 139-42.

11) Ueda $S$, Ito $Y$, Konnai $T$, et al: Delayed cardiac rupture occurring two months after blunt chest trauma. Gen Thorac Cardiovasc Surg. 2011; 59: 45-7.

12) Pollak S, Stellwag-Carion C: Delayed cardiac rupture due to blunt chest trauma. Am J Forensic Med Pathol. 1991; 12: 153-6. 


\author{
ABSTRACT \\ Delayed cardiac rupture after blunt chest trauma associated with multiple rib fractures \\ Yuriko Tomioka $^{1}$, Hisashi Yoshimura ${ }^{2}$, Masato Fukuoka ${ }^{3}$, Yoshiaki Tatsumi ${ }^{3}$ \\ ${ }^{1}$ Department of Surgery, Mimihara General Hospital \\ ${ }^{2}$ Seiyu Clinic \\ ${ }^{3}$ Department of Surgery, Steel Memorial Hirohata Hospital
}

A 61-year-old man who sustained bruising after falling from a 1.5-m high fence was admitted to our hospital. On arrival, he was conscious and clinically stable. Chest computed tomography revealed multiple left rib fractures and hemopneumothorax; therefore, chest drainage was performed. He suddenly lost consciousness $56 \mathrm{~h}$ post-injury. Because his radial artery was not palpable, chest compression was performed; and he immediately regained consciousness. Over a short period of time, $140-\mathrm{mL}$ blood was drained from the chest tube; thus, a second computed tomography was performed, which revealed extravasation around the heart apex. Lateral thoracotomy performed around the left fifth intercostal space revealed a sharp fractured edge of the fifth rib in contact with the pericardium, and bleeding immediately below the site. Blood oozed when the pericardium was incised; a 10-mm rupture to the left ventricle was discovered, which was repaired by inserting felt strips and pledgeted mattress sutures, thus restoring hemostasis. In this case, there was no pericardial effusion on admission. Thus, we believe that although the fractured rib caused the hemorrhage, it did not penetrate the pericardium; but as it was in contact with the heart for a long period, it led to a delayed cardiac rupture.

(JJAAM. 2014; 25: 827-32)

Keywords: cardiac tamponade, left ventricle rupture, hemopneumothorax, non-penetrating Received on August 20, 2014 (14-059) 